\title{
Security and development - are they two sides of the same coin? Investigating India's two-pronged policy towards left wing extremism
}

\author{
Ipshita Basu*, Institute of Governance Studies, BRAC University, \\ Dhaka, Bangladesh
}

\begin{abstract}
In this article, I investigate India's two-pronged policy approach, which combines security and development intervention to address the root cause and symptoms of left wing extremism. While the two policy sets are meant for two very distinct policy subjects - the angry extremist and the neglected poor - I argue that in renewing state legitimacy against internal dissent, development goals are made to coincide with traditional security concerns for state survival and stability. In this article, I unpack three representations of the problem of left wing extremism - as terrorism, as a parallel regime and as a 'political disorder' - in relation to the particular policy responses they each advocate. Through these three representational frames, the effects that the security imperative has on the idea and practice of development are uncovered.
\end{abstract}

\section{Introductio}

n

In the last decade, while India has successfully positioned itself as one of the emerging giants in the global economy, inside its borders it has had to cope with the rise of left wing extremism. The Naxalite Movement, which is the name given to this Maoist-inspired rebellion, is considered to be the most serious internal security challenge the Indian state has ever faced, and is a violent reminder of the need to resolve long-standing disputes over land displacement, poverty and social oppression. In its chequered history, the Naxalite Movement has been a testimony to the resilience of the underbelly that has paid the price for India's economic success. For the rural peasantry and forest tribes, the Indian state has made available a set of affirmative measures to help them integrate with the mainstream. But provisions for reserved public sector jobs, seats in elected offices and educational institutions do not entirely fill the gaps created by grinding poverty and exploitation, and thus reasons to carry out a struggle outside the parliamentary system remain. As a result, there is - on the one hand - a preponderance of politics surrounding the reservation system, wherein minorities listed in the schedule category are mobilised such that they use their ascribed identity to bargain for resources from the state and form a political majority of their own (as typified by the Bahujan Samaj Party). On the other hand, there is the politics of left wing extremism, which arms some of the poorest and most dispossessed amongst India's marginalised communities with the ideology of violence.

The Naxalite Movement began in May 1967 in a remote village called Naxalbari in Darjeeling district, when a group of tea plantation workers revolted against the landed gentry. The embers of violent revolt that this sleepy hill-station had sparked soon spread like wildfire to neighbouring districts of West Bengal, Bihar and Andhra Pradesh, where similar peasant movements found a new inspiration in the ideology of armed rebellion. By the end of the Emergency in 1977, Naxalism was believed to have been completely liquidated. Eventually, however, surviving activists revived and consolidated the movement and it now looms in regions which host some of the poorest people and the richest resource bases in India, stretching from its main nerve 
centre in Andhra Pradesh and Bihar to adjoining districts in Orissa, Chattisgarh, Jharkhand and West Bengal and moving further out into Madhya Pradesh, Kerala and Maharashtra.

The Naxalite Movement is - in a sense - the Frankenstein that a feudal cum neoliberal economy has generated. Many years of land displacement, poverty and gaping inequality, combined with the Indian state's recourse to violence to contain the space for public dissent, has given way to this form of political violence. Typically, the Indian state's response to the problem of Naxalite violence has involved a dual policy of treating the symptoms and the root cause. While the symptoms are understood as anger and frustration expressed through violent extremism, warranting more policing and militarised means of containment, the root cause is explained through the relative under-development and backwardness in some regions of the country, leading to policies for speedier and more welfareoriented development. In taking latent responsibility for the growing brand of left wing extremism, the Indian state proposes a programme that brings together the law and order approach with the socio-economic one. At once, it allows the state to protect itself from violent rebellion, creating a safe and stable environment for its citizens, while also reaching out to those angry and neglected millions who remain untouched by the golden hand of development.

This dual approach could be a sign of hope for some. At least, despite its contested ideology of violence, the Naxalite Movement has brought some sense of urgency to resolve long-neglected problems. It may seem that it highlights the negative consequences of development and sanctions the importance of the welfare state, even as the Indian economy opens itself to a market-based neo-liberal model. However, in this article, I aim to problematise this two-pronged policy. The first issue that I raise is to do with the logic of this approach. If the policies have been designed to address the same problem - namely the rise of left wing extremism - then how does the policy discourse distinguish between two objects of intervention? In other words, how does state policy differentiate between the offender who will meet the coercive arm of the state and the victim who will receive the welfare arm? This question is part of a wider issue concerning how the securitisation of problems related to poverty and displacement transforms the idea and practice of development. Does it highlight the importance of welfare and reform in the existing development programmes? Or does it make development goals coincide with security goals, such that they are both ultimately aimed at state survival and maintaining the existing system?

Generally, the linking of development goals with security concerns has at least two potential implications on the overall development agenda. One is that further coercive measures might be taken in the name of development, wherein the security imperative overrides the emancipatory goals that development carries. The other is that there may be a broadening of the security discourse - as we see in the human security agenda - such that it covers various facets of human survival from poverty and inequality, to health, education and freedom from fear and discrimination.

In my investigation of the Indian state's two pronged policy of security and development, I am not attempting to argue that security discourse is inevitably coercive. Rather, I am contesting the notion that the two sets of policies can be considered as separable from each other. In fact, in the Indian state policy towards the Naxalite movement, what we find is that development and security goals coincide to the extent that development initiatives are collapsed within wider interests. This 
serves as a means of restoring the legitimacy of the developmental state and ensuring state survival amidst violent resistance.

The Indian state's recourse to a policy that combines security with development has to be viewed against the context of the neo-liberal restructuring which the Indian economy has undergone over the past 25 years. While the Indian state has been prompt in instituting policies that favour private investment, industrial growth, infrastructure development and a shift towards agricultural exports, initiatives for land reform, rehabilitation and resettlement policies, poverty alleviation and protection against corruption and discrimination have been much slower.

The Naxalite Movement has proliferated in these circumstances. Rather than understanding this movement as an indication of some of the problems with the mainstream economic policy, the Indian state views the movement as an obstacle to the successful functioning of its economic order. The result is that internal dissenters are taken as the enemy within, who have to be flushed out as soon as possible for development to continue to show its results. While this has severely contained the space for debate and negotiation over development issues, it has also resulted in the creation of policies that are mainly oriented towards sustaining the existing development regime.

Over the past seven years, successive annual plans from the Ministry of Home Affairs have standardised the socio-economic measures to contain Naxalism around road construction, health care reform, decentralisation of local governments, job guarantees and funding for development of backward areas. These initiatives are intended to increase the speed with which development reaches remote areas that have not so far experienced the benefits of modernisation and struggle to catch up with the pace of growth in the rest of the country. The Naxalite Movement is believed to flourish out of people's frustration and ignorance of the success of India's development regime. Therefore, steady and urgent attempts by the state to show development activities in these regions would result in the people themselves forcing the Naxalites to leave. Through these policies, development is used as an instrument to win back people's loyalty to their state and defeat the Naxalites. It must also be noted that some of these remote under developed regions are also the richest sources of minerals and forest reserves, which explains why some of the measures taken under the socio-economic approach are also constitutive of initiatives to encourage more private investment in these areas.

To sum up, securitisation of development has to a large extent restricted the avenues for criticism. It has hardened around repressive measures against internal dissenters - the so-called anti-development terrorists - who are considered to be the main obstruction to the successful implementation of the state's development programme. The very presence of such an internal enemy allows for coercive measures to be taken wherever local resistance against development intervention takes place. Events in Nandigram in West Bengal in 2007 - when the state government came down heavily on protests against expropriation of land by a MNC - and the ongoing Operation Green Hunt in the jungles of Chattisgarh where Maoists as well as innocent tribals are indiscriminately attacked to pave the way for a private takeover of forest and mineral reserves - are stark reminders of this situation. 
It has also resulted in the narrowing of the problem of development to people's inaccessibility and ignorance of the benefits that development can bring. The emphasis has shifted to integrating regions and people's consent with the overall development machinery, so that more inroads for state-private intervention can be made without facing much local resistance. As a result, continuing issues of poverty, inequality and displacement due to development are pushed further to the margins of the developmentagenda.

My investigation is inspired by policy as discourse theory, which takes the representation of problems for which policies are designed as constitutive of the process of policy making (see Hawkesworth 1988; Shapiro 1997; Bacchi 2000). The way in which the problem of Naxalism is constructed determines the subjectivity of the target groups, de-lineates the issues that can be acted upon while silencing others and determines the scope for change and redressal.

A second influence for my analysis comes from the Copenhagen School of Security studies, which considers securitization as the process whereby (through speech acts) issues are positioned as an existential threat to a particular referent object and accepted as such by a relevant audience, in turn enabling emergency measures (Buzan and Waever 1997; Buzan et al. 1998; Williams 2003). Thought about in this way, securitisation stands for a discursive process that takes an issue from the level of 'normal deliberative politics' to 'national crisis' and 'state survival', where speed rather than restraint, unanimity rather than debate and short-term rather than long-term goals become the norm. The securitisation of left wing extremism, for instance, has key implications on development decisionmaking, as it involves the restoration of state legitimacy against an internal enemy, which strikes where the state is weakest - its failure to deliver basic services to correct relative inequality and displacement. How does securitisation allow for more coercive measures to be taken in the name of development? What ideas and measures of development are produced from this link between security and development?

I will attempt to answer these questions by assessing three different representations of the problem of the Naxalite Movement. Each of these representations is related to a particular policy alternative. They are: the Naxalite Movement as terrorism, the Naxalite Movement as a parallel regime to the state and the Naxalite Movement as political disorder. Before I take up each in turn, let us look at how left wing extremism has come to the particular historical juncture that we witness today.

\section{A Phoenix from the ashes - the fall and rise of left wing extremism in India, 1965-2009}

When in September 2004 two of the biggest Naxalite parties, the People's War (PW) and the Maoist Communist Centre (MCC) merged to form the CPI(Maoist), it was 
recorded as a landmark moment in the history of the Naxalite Movement. It is estimated that their combined strength amounts to about 9000-10,000 armed fighters with access to about 6500 firearms and with possibly a further 40,000 fulltime cadres (Economist 2006). This merger was one amongst other events that formed the backdrop of Prime Minister Manmohan Singh's speech on the occasion of India's Independence Day in August 2006, when he declared that '. . . the problem of Naxalism is the single biggest security challenge ever faced by our country'. This remark captured the attention of many security analysts who soon began to discuss what was once thought of as a thinly spread out peasant rebellion in the tribal dominated districts of the country, with the same level of priority as insurgency in Kashmir and the North East (see Podder 2007; Nayak 2008; Iyer 2009; Strategic Comments 2010).

This merger was the result of a series of unification initiatives taken up by Naxalite factions since the late 1990s. One member in this partnership, the PW, was formed in August 1998 after the CPI(ML) Party Unity (PU) - which had a stronghold in the Jehanabad and Gaya districts of Bihar - merged with the People's War Group (PWG), which was highly influential in Andhra Pradesh. The other half of the partnership, the MCC - which was mainly active in Bihar - had formed an alliance with the Revolutionary Communist Centre of India-Maoists in 2003. The MCC's beginnings go as far back as 1969, the early stages of the Naxalite movement when a group of leaders including Kanu Sanyal disagreed with Charu Mazumdar's decision to discontinue Dakshin Desh, the party journal, and thus formed their own party. On the other hand, the PWG was formed in 1980 by Kondapalli Seetharamiah when he broke off from the CPI(ML), which is the parent organization of the Naxalite movement. Over the years, both parties have, to an extent, earned a reputation for being hard-liners who stuck to eschewing parliamentary practices for armed agrarian revolution. Since the PWG had already established a parallel regime in Andhra Pradesh, its merger with MCC in Bihar meant that it would have a wider territorial reach, and would define the dominant vein of the Naxalite movement in India. Kujur (2008) of the Institute of Peace and Conflict Studies in Delhi considers the tactical line of these parties as one of the main reasons why the Naxalite Movement has come to be considered as an internal security problem.

Other events which add to the thesis that the Naxalite movement is a serious security challenge include: the formation of a network of Maoist parties in South Asia called the Co-ordination Committee of Maoist Parties and Organisations of South Asia (CCOMPASA), of which the PWG and MCC are also a part; the active links with the Communist Party of Nepal (Maoist) and rumours of further links with ISI in Pakistan and the Communist Parties in Sri Lanka; and finally the Compact Revolutionary Zone - more popularly known as the Red Corridor - that comprises the 170 districts under Naxalite control and which could potentially break away the resource rich regions from the rest of the country.

But how did a movement which began with one incident of armed revolt in Naxalbari and was crushed within 72 days by the West Bengal police come to this stage? For one, the Naxalbari episode in May 1967 coincided with major ideological rifts within the Communist movement in India (Banerjee 1980). While most in the CPI(M) chose the option of participating in elections to bring about the democratic revolution, others within the party saw this as a moment of revisionism and cooption and chose to carry out the armed revolution outside the auspices of the party. Charu Mazumdar, who was the key figure to lead this initiative, formed the All India 
Coordination Committee in November 1967, which was renamed as the CPI(ML) in May 1969. Some members of the CPI(M) in West Bengal, Andhra Pradesh and Bihar joined this new party while others, such as the MCC led by Kanu Sanyal and the Andhra Pradesh Revolutionary Communist Party (APRCP) led by Nagi Reddy, supported the ideology but chose to continue with their independent movements. Interestingly, the carriers of the original party formed by Charu Mazumdar - the CPI(ML) - are now seen as the revisionists, while the more recent avatars of the APRCP and the MCC, who have formed the CPI(Maoist), are the main political base of the contemporary revolution.

By 1975, most of the Naxalite factions in West Bengal and adjoining Bihar were assumed to have been liquidated with the help of the state's law and order apparatus. The counter-insurgency operations initially only involved the state police, who dealt with revolts as instances of anti-social and criminal behaviour. Then by 1970 colonial anti-terrorist acts were reinstated and paramilitary forces were deployed, which finally culminated in the heavy hand of the Emergency from 1975 to1977. After the Emergency most in the establishment, as well as the intelligentsia who had once supported the radical left wing movement, began writing obituaries that declared the revolution to be an adventurist campaign that had been erased for good (Roy 1975; Ray 1988).

However, when the Emergency was lifted in 1977 surviving activists began to rethink their ideological and tactical views. Some, such as Satyanarayan Singh of the CPI(ML) in Bihar, were willing to negotiate with the state in order to release prisoners and find some legitimacy in the new political environment. In exchange for signing a declaration that they would support state policies, be patriotic and base their ideology on Marxism rather than violence, the Home Minister Charan Singh repealed the Maintenance of Internal Security Act (MISA) and released all Naxalite prisoners unconditionally (Gupta 2004). Others, such as Kanu Sanyal, Asim Chatterjee and Souren Bose supported this initiative to restart the movement through open front organisations, but at the same time decided to prepare themselves for an armed revolution in the future.

Thus, in the post-Emergency phase of the Naxalite movement, there was a serious effort by the main Naxalite parties such as the MCC, CPI(ML), PWG and PU to mobilize through front organisations as well as armed wings. While the front organisations were the main party organs representing workers' rights in the democratic mainstream and in electoral politics, the armed wings were meant to defend against incidents of repression in the short-term whilst also pursuing the more long-term aim of bringing about a radical change through armed revolution. Since then, as is well-known, there has been a gradual shift in preference for the armed strategy. The more widely held explanation for this is that the Maoist's ideology has trapped them into a spiral of violence against the state and their own internal factions, because of which they are now unwilling to give up their armed wings and partake in peaceful negotiation. However, what this explanation leaves out is the role that the central and state government's systematic banning of front organisations of the extreme left has played in encouraging more underground activities and armed wings. 
In Bihar, which became one of the main centres of the Naxalite movement in the post 1977 period, three of the main parties met with a similar fate. The CPI(ML), which was most unambiguous about pursuing a parliamentary path, first launched Bihar Pradesh Kisan Sabha (BPKS) which carried out a successful village level campaign for land reform and wages (Louis 2000). Its electoral wing - the Indian People's Front - which was later disbanded and replaced by the CPI(ML), performed well in the state and assembly elections, winning one seat in the 1989 parliamentary election and seven seats in the state assembly election. However, in 1990 the Bihar government banned the BPKS and declared it to be a terrorist organization. In response, the CPI(ML) in its 1992 state conference, referring specifically to the conditions in Bihar, decided that it would have to carry out armed struggles in regions where there were private caste armies and the police were continuing to repress their open fronts (Singh 1995).

Similarly, PU - which formed an open front organization called Mazdoor Kisan Sangram Samiti (MKSS) in 1982 for agricultural workers - was banned in 1986 after an encounter in which MKSS activists were gunned down by the police. The Bihar state blamed the MKSS for this incident and in 1987 it was re-launched under the name of Mazdoor Kisan Mukti Manch, taking on a much more militant character.

Finally the MCC, which from the start had emphasised the armed strategy and jointly pursued front organizations such as the Krantikari Kisan Committee and an armed wing called the Lal Raksha Dal, became intertwined with caste-based violence in Bihar. For responding to the private armies of the landowning Bhumihar, Kurmi and Yadav caste with annihilation campaigns and massacres in upper caste dominated areas, it was condemned even by the CPI(ML) for degenerating into a caste-based murderous party (Bhatia 2000).

In Andhra Pradesh, where the Naxalite movement is much more deeply established as a parallel regime, the response of the state government has been somewhat mixed. Following the death of Charu Mazumdar in 1972, Kondapalli Seetharamaiah, Suniti Kumar Ghosh and K.G. Sathyamurthy formed the Coordination Committee of CPI(ML). In the post-emergency period, they decided to avoid militancy until they were more fully prepared, but at the same time chose not to participate in elections. Later, in 1980, Seetharamiah broke away from the COC CPI(ML) to form the PWG. This reflected a major split in the CPI(ML) which until then had defined the dominant line of the Naxalite Movement. The rift was mainly due to a section of the leadership who believed that the pursuit of revolution through the legal and parliamentary path was gradually dissolving into a reactionary and opportunist campaign. The PWG was therefore formed with a view to revive the armed struggle that Charu Mazumdar had once encouraged, but through pursuing a mass-mobilised PW rather than selective annihilation campaigns that often degenerated into individual terrorism.

Eventually, the PWG displaced the CPI(ML)'s hegemony over the Naxalite movement as it stretched its reach from its home turf in Andhra Pradesh to Bihar when it merged with PU in 1982. Over the next few years it spread into Orissa, Chattisgarh and West Bengal as it merged with smaller parties in these neighbouring regions. Finally, in 2004, it merged with MCC, marking a significant consolidation of the Naxalite Movement which the PWG has gradually come to dictate over the last two decades. 
The Andhra Pradesh government has been quite equivocal in its policy towards the Naxalites. While on the one hand there have been initiatives for peace processes and attempts to recognise the Naxalites as part of the political mainstream, there have equally been attempts to curb them through stringent counter-insurgency measures including the 'notorious' Andhra Greyhounds, a well-trained antiguerrilla force that is immune from all legal safeguards. Over the years, evidence of mutual support between Naxalites and political parties during election campaigns (Balagopal 2006) has emerged at the same time as a sense of mutual suspicion, has developed as each side has gone back on its promises during brief periods of peaceful negotiation. Initially, during his election campaigns in 1982 N.T. Rama Rao embraced Naxalites by calling them Deshabhaktulu (patriots) but later when he came in power in 1986 he declared war on revolutionaries and encouraged police camps and encounter killings. Later, in 1989, Chief Minister Chena Reddy launched a liberal policy which allowed Naxalites to conduct public meetings and withheld police interference in their activities. Despite having a novel approach of legitimising Naxalite politics and carrying out development initiatives such as the Remote Areas Development Programme, the policy lasted only for a year. This time, the Naxalites were blamed for exploiting the state's soft approach in order to continue with extortions and expand their arms base. Chenna Reddy decided to resume the hardline after facing criticism from the opposition, and by 1992 PWG and its front organisations were banned.

Between 1994 and 2004, during the N.T. Rama Rao and Chandrababu Naidu government, the state's response to the PWG became more focused on counterterrorism measures. While the need for addressing socio-economic problems was recognised, the government refused to see Naxalite activists as anything other than terrorists and criminals (Reddy 2008). As the violence in the state escalated, an attempt for peace talks was made in 2002, but was aborted within three months amidst accusations from both parties. PWG activists reported police encounters that claimed the lives of their key leaders, while the A.P. government suggested that Naxalites increased extortions when the ban was lifted. In 2004, hopes were renewed when the Congress government led by Rajashekhar Reddy began peace talks, but even this was abandoned after two rounds of meetings.

In order to respond to the Naxalite problem, the Ministry of Home Affairs at the centre has periodically organised inter-state conferences in which there has been some sort of a consensus that the overall approach has to be a multi-pronged one, including police modernisation, developing co-ordinated intelligence networks between states, filling critical gaps in infrastructure and development of remote areas and persuading people through public grievance system and local resistance groups. However, the main responsibility lies with individual state governments who devise their own ways of dealing with left wing extremism, while the centre plays a supportive role by providing funds through different central government programmes. $^{1}$

As a result,

there are some variations in the policies that different state governments have devised. The A.P. government, for instance, has relied on counter- insurgency measures punctuated by peace talks, most notably in May 2002 and October 2004. However, there is some amount of scepticism that these peace talks usually occur after a new party comes into power, therefore indicating a possible nexus between the PWG and the winning party (Balagopal 2006). Also, as the PWG has spread to other districts and the Naxalite movement is seen as national problem, other state governments consider meetings with PWG leaders as doing a disservice to 
the overall strategy. The option of dialogue and negotiation has therefore gradually become quite remote. The official verdict is that dialogue will be allowed only if the Naxalites completely give up their arms.

Meanwhile, in Chattisgarh in June 2005, Mahendra Karma, a Congress Party leader, devised Salwa Judum - a local resistance group comprising of tribal people who supposedly took up arms to defend themselves against the Naxalites. As part of an initiative to wean away popular support from the Naxalites, it resulted in one of the worst massacres in the region. Although the campaign was later condemned in the Indian Parliament, it has had a more lasting effect in introducing a policy wherein the same tribal activists are inducted as Special Police Officers or trained in the Counter Insurgency and Jungle Warfare Training College which was recently set up in the state. With this, development reform for tribal people seems to have taken a vicious turn. There are two options for the tribal youth - either to be a Naxalite activist who takes up arms against the state, or to become a government employee and direct their anger against the Naxalite.

Elsewhere, the state governments of Bihar, Jharkhand and Orissa have, since 2005 , introduced surrender policies for Naxalite activists. In order to encourage the rebels to return to the mainstream, they are given rehabilitation packages of Rs. 1.5 lakhs $(\$ 1500)$ which they can use after completing three years of probation. For every weapon they surrender they are given cash compensation - Rs 15,000 (\$330) for an AK 47 to Rs. 3000 (\$66) for a pistol. In addition, a monthly stipend of Rs. 2000 (\$50) to undergo vocational training, a bank loan guaranteed by the government to start up a business and a house through the Indra Awaz Yojna are also available.

When Naxalite activists surrender to the police, it is hardly a secret operation but is a highly publicised media event. Recently, in Orissa in March 2010, when around 25 Naxalites - mostly young tribal men from Gajipur district - surrendered, it generated headlines. Between footage of AK-47 rifles laid out on a table and emaciated and confused looking young men dressed in soldier's costumes, the mediasavvy police took centre stage, explaining that the activists chose to return to the state because they were disillusioned by the ideology and violence advocated by the Naxalite leaders. The success was not so much the surrender and possible rehabilitation of the frustrated youth, but the state's opportunity to direct its propaganda against the Naxalite movement.

Still, despite experimenting with different policy strategies, the number of Naxalite attacks in India has levelled at an average of 1561 between 2004 and 2008 (see Table 1). The intensity of violence, which is the number of deaths per attack, has increased marginally from $0.44 \%$ to $0.45 \%$ in the period from 2008 to 2009 . From these statistics two issues stand out. One is that despite policy initiatives that combine the security and the development approach, the level of violence has remained stable. The second is that contrary to reports that Naxalites are in possession of sophisticated weapons, it appears that the intensity of their attacks has not significantly increased. Part of the reason why left wing extremism does not seem to have been quelled, despite attempts to address the root cause as well as the symptoms, is to do with the way in which the problem of Naxalism is represented. I turn to this question in the following sections where I evaluate the three types of representations and the particular policy approaches of which they are constituted. 
Table 1. State-wise incidents of Naxalite violence from 2004 to 2008.

\begin{tabular}{|c|c|c|c|c|c|c|c|c|c|c|}
\hline \multicolumn{11}{|c|}{ State-wise Naxalite violence from $2004-2008$} \\
\hline \multirow[b]{2}{*}{ States } & \multicolumn{2}{|c|}{2004} & \multicolumn{2}{|c|}{2005} & \multicolumn{2}{|c|}{2006} & \multicolumn{2}{|c|}{2007} & \multicolumn{2}{|c|}{2008} \\
\hline & Incidents & Deaths & Incidents & Deaths & Incidents & Deaths & Incidents & Deaths & Incidents & Deaths \\
\hline Andhra Pradesh & 310 & 74 & 535 & 208 & 183 & 47 & 138 & 45 & 92 & 46 \\
\hline Bihar & 323 & 171 & 186 & 96 & 107 & 45 & 135 & 67 & 164 & 73 \\
\hline Chattisgarh & 352 & 83 & 385 & 168 & 715 & 388 & 582 & 369 & 620 & 242 \\
\hline Jharkhand & 379 & 169 & 312 & 119 & 310 & 124 & 482 & 157 & 484 & 207 \\
\hline Madhya Pradesh & 13 & 4 & 20 & 3 & 6 & 1 & 9 & 2 & 7 & - \\
\hline Maharashtra & 84 & 15 & 94 & 53 & 98 & 42 & 94 & 25 & 68 & 22 \\
\hline Orissa & 35 & 8 & 42 & 14 & 44 & 9 & 67 & 17 & 103 & 101 \\
\hline Uttar Pradesh & 15 & 26 & 10 & 1 & 11 & 5 & 9 & 3 & 4 & - \\
\hline West Bengal & 11 & 15 & 14 & 7 & 23 & 17 & 32 & 6 & 35 & 26 \\
\hline Kerala & 5 & - & - & - & 2 & - & 8 & - & 2 & - \\
\hline Karnataka & 6 & 1 & 8 & 8 & 10 & - & 7 & 5 & 8 & 4 \\
\hline Haryana & - & - & - & - & - & - & 1 & - & 2 & - \\
\hline Tamil Nadu & - & - & 2 & - & - & - & 1 & - & 2 & - \\
\hline Total & 1533 & 566 & 1608 & 677 & 1509 & 678 & 1565 & 696 & 1591 & 721 \\
\hline
\end{tabular}

Source: Ministry of Home Affairs, Annual Report 2008-2009. 
Naxalite movement as terrorism: policy of control and containment Soon after the first incident of land grabbing in Naxalbari in May 1967, the police forces decided on some guidelines on their attitude towards the 'miscreants'. While they were firm in their resolve to end lawlessness, they decided that a humane and restrained attitude on the part of the forces would help them win the trust and confidence of the people (Mukherjee 2007). Even the statement issued by the Communist government, which described the activists as 'law-breakers' and condemned their violent methods, accepted that the peasants may have just grievances over the feudal land distribution system (Statement of Chief Minister Ajay Kumar Mukherji May 1967, cited in Mukhopadhyay 2006).

It was later, in 1970, that official discourse associated the terms 'terrorist' and 'extremist' with Naxalites. These terms provided the basis for reviving the Bengal Suppression of Terrorist Outrages Act 1936 in September 1970, and for passing the Prevention of Violent Activities Bill in November 1970. The representation of the Naxalite Movement as 'terrorist' followed from counter-terrorism legislation which allowed the police to act with impunity, rather than the actions of the so-called 'militants' themselves. From hereon, instead of taking 'appropriate action,' the police - aided by the army - were instructed to take 'unusual' and 'bold' steps in order to confront the 'unusual' crisis situation (Calcutta Police Gazette, 23 October 1970, cited in Mukhopadhyay 2006). During the Emergency, the Maintenance of Internal Security Act 1971 was applied against Naxalite leaders to arrest them on the charge of being a threat to national security. Later, in 2002, the BJP government used the Prevention of Terrorist Atrocities Act (POTA) to arrest suspected Naxalites without warrants. ${ }^{2}$ This was repealed by the Congress-led UPA government, which repackaged the bulk of the POTA provisions in the Unlawful Activities Prevention Act 1967.

To a large extent, the main purpose of fixing the label 'terrorist' on Naxalites is to aid indiscriminate arrests of people who are suspected of being activists or supporters, because through these legislations the regular norms and procedures as well as civil liberties involved in arrests and enquiries are suspended. Although these exceptional powers have been invoked as short-term measures to curb Naxalite violence, most of the provisions of these laws have become a permanent part of the legal system and therefore stretch the state's exceptional powers indefinitely (Tharu 2007).

The association of the Naxalite Movement with terrorism and insurgency gives way to a whole set of security measures to contain the movement - from deploying the army and paramilitary forces, to setting up police camps in the rural hinterland, establishing jungle warfare training institutes, more surveillance and intelligence networks, arrests without evidence and the use of torture in police enquiries. However, as Shamuel Tharu (2007) indicates, given that the legal sanction to invoke exceptional powers is already in place and the state does not need to justify the breaking of rules in its handling of the Naxalite problem, the constitutive role that the 'terrorist' label plays in escalating the crisis to the point that it needs extraordinary methods of containment enters different arenas.

One such arena is the two-pronged policy of treating the Naxalite insurgency with law and order and socio-economic methods. Even as there is sufficient evidence that the root cause of the problem lies in inequality and development and therefore needs effective policies oriented in this direction, the logic of Naxalite 'terrorism' 
helps sustain the basis of the security policy. Within this framework, while the state recognises the grievances that cause radical rebellion, it does not recognise the legitimacy of the activists themselves. Therefore, in colouring the Naxalite Movement mainly through the illegitimacy of the violence used by non-state actors, the state finds the legitimacy for establishing its own monopoly over violence and for continuing its security policy which is meant to end only when the Naxalites completely abjure violence and surrender their arms (Ministry of Home Affairs 2008, 2009).

The terrorism argument plays a crucial role in drawing a concrete and impermeable line between the offender - the threat, the enemy, the insurgent who is external to society - and the victim, the disgruntled poor, young, unemployed, tribals who are easy recruits for the movement. Rejecting the possibility that the victims could themselves have turned into rebels, this approach advances two contradictory propositions. For the 'rebels' who only understand the language of violence strong action would be needed, whereas the 'poor recruits' who inadvertently join the movement would have to be rehabilitated back into the mainstream. On one occasion, the Home Minister Shivraj Patil, when arguing for alternatives to a coercive approach towards Naxalites, suggested that unlike insurgents in Kashmir, Naxalites are 'our brothers and sisters,' and could be brought back to the mainstream through negotiation and the provision of jobs (Lok Sabha Debate, from hereon LSD, Patil 2005a). Some members of parliament challenged this remark by re-asserting that those who engage in proxy war are a threat, and therefore cannot be regarded as members of Indian society (LSD Malhotra 2006). They went on to caution that any attempt by the state to negotiate with armed insurgents would indicate ambiguity and softness in its counter-terrorist policy, and insurgents would only harness this to consolidate their strength (LSD Mahtab 2005; Swain 2006). Therefore, linking the Naxalite movement with terrorism not only makes the distinction between the target groups for the welfare and coercive policies possible, but also suggests that this distinction is necessary for state survival and legitimacy.

In the representational framework of terrorism, the identity of the Naxalite activist is abstracted from the specifics of who he is, or why and how he comes to exist. Instead, the Naxalite movement is seen as a scourge that creates disorder in society, or a phenomenon that is unnatural and unexplainable. At best, the movement is seen as a form of organised violence that is expansionist and driven solely by the pursuit of power.

When the movement is collapsed into other forms of terrorism, its political ideology of class struggle becomes largely irrelevant. It has to be seen for what it is criminal, violent and unredeemable. The association with terrorism also suggests that its politics is based on radicalisation of the poor. However, in a sense it is even more dangerous than religious radicalism because the extreme views are directed on the areas that the state has neglected or failed to deliver. In response, it asks for a politics of consensus-building and unanimity from the state representatives. For instance, when discussing incidents of Naxalite violence, time and again members of parliament are urged to speak from a non-political stance, to use their platform for agreement rather than debate and to refrain from partisanship (Chaliha 2004; Patil 2005b).

While the problem of Naxalite terrorism sanctions policies for development reform, it highlights that these should always be considered in conjunction with the security approach. It is advised that even criticisms of state performance and police action in dealing with the crisis are acceptable, as long as such a critical approach is also adopted in regard to the terrorists and their actions (LSD Patil 2005b). There is an underlying anxiety amongst those who use the terrorist lens that those who 
privilege the need for the socio-economic approach dilute the urgency to contain violence and provide an undue rationality to criminal activity by describing it as a class struggle (Kumar 2005; Mahtab 2005; LSD Patil 2005b).

As a result, in the policy discourse that approaches the problems of Naxalism as terrorism, development programmes are seen as part of the overall process of counter-terrorism. In an interview, the Director of the Counter-Insurgency and Jungle Warfare Training School in Chattisgarh describes civic action amongst the villagers as a feature of one type of counter-insurgency operation called patrolling (Srivastava 2008). When forces patrol an area, development activities facilitate local linkages by building the villagers' trust and respect for the establishment. They are thus able to gain access to information about the enemy, as well as divert the villagers' loyalty away from the Naxalites to the state.

Finally, development is considered as some kind of palliative that calms the anger and frustration in the minds of the neglected and poor who live in forest areas. In this respect, development is part of an overall strategy of containing violence, which involves reassuring the marginalised through development activities in their areas as well as instructing them about the benefits of modernisation (Kumar 2004; LSD Chakraborty 2005; Kumar 2005; Patil 2005b; Rao 2009). As if, the tribals are the subjects of change and reform and not the development policies that cause their anger and frustration.

\section{Naxalite movement as a parallel regime: policy of reforming and re-legitimising} the state

Between the Naxalite Movement and the Indian state there is what may be described as a causal relationship. The general view is that since the post-colonial Indian state has failed to bring about an efficient delivery mechanism for its poverty alleviation and rural development programmes over the last 60 years, the Naxalite Movement has entered the rural milieu by providing the basic services which the state has failed to deliver. Gradually, it has set up a parallel regime not only through terror tactics but by filling up the vacuum that existed in the absence of the state's administrative machinery (Ahuja and Ganguly 2007). In areas far-removed from the formal judicial system, it has set up people's courts which, although infamous for their ruthless judgements, offer a speedy and inexpensive alternative for the poor and subordinate groups. They have had some success in redistributing land from powerful and unpopular landlords to the landless. Minimum wages have been set up, most notably for those who collect minor forest produce like tendu leaves along with introducing other developmental activities such as schools, mobile medical units, irrigation reservoirs and community kitchens (Louis 2000; Bhatia 2006; Garg 2008).

This causal relationship, which results from the Naxalites infiltrating the areas where the state is remote or even absent, goes hand in hand with another relationship - that of the nexus and the complicities between them. This, in a sense, tarnishes the self-image of the Naxalite as a sort a Robin Hood figure who takes from the stateelite nexus to save the poor, but also equally throws scepticism on the official state which is seemingly, in its rhetoric, at war with the Naxalites. The continuities between the state and the Naxalites take shape in the informal economy, as Kelly and Shah (2006) uncloak from the market of protection in Jharkhand, wherein the MCC cadre, like state officials in the past, sell protection to local entrepreneurs and 
state officers to secure their share of the illicit cut from the revenue that is allotted for development schemes in the area. While the official story blames the Naxalites for disrupting development by perpetuating an extortion racket, the realities on the ground show that this illegitimate economy pre-dated the Maoists and what is more is a self-creation of the state itself.

The Maoist links that Kelly and Shah (2006) make visible are what Harris-White (2003) describes as the 'shadow state' - a network of brokers, advisers, political workers and crooks who have surrounded the official state, depriving it of its funds to secure the private benefit of those involved. Over the years, while the 'official' state introduced the Public Distribution System and disbursed funds for the Integrated Rural Development Programme, rich landlords complicit with the bureaucracy perpetuated an economy based on black marketing, hoarding and bypassing the law (Ahuja and Ganguly 2007). So, the official state had already begun to be hollowed out by the shadow state and when the Maoists stepped in they struck where the state was weakest - its own illegitimate by-product. They developed further links with this shadow state to establish themselves in the locality and then gradually took over as the leaders of this parallel administration.

The threat that the Naxalite Movement poses therefore follows not only from the security imperative based on its growing military strength and having its eyes on capturing the state, but also from a much deeper issue of the political legitimacy of the state. The spatial spread of areas where Maoists' have set up a parallel administration is therefore worrying, not because it could potentially form a red corridor across India and then eventually take over Delhi as the official story goes, but because it strikes at the very core of the state, its own political subjectivity. The policies that emerge from representing Naxalism as a result of state failure are aimed towards restoring the political legitimacy of the state, as will be explained subsequently.

In the State-Naxalite framework, the Naxalite takes the meaning and substance of its own subjectivity from the subjectivity of the state, more precisely the decline in subjectivity of the state. Without the failure of the state in delivering basic services, there would be no Naxalite. And thus follows the explanation that the Naxalite - by filling the absence of the state machinery - has emerged as a parallel administration, to the extent that it looks like a mirror image of the state - power-hungry, bloated with extortion and corruption, oppressive to the people over whom it claims responsibility. However, even though their subjectivities are so mutually constitutive, in order to restore the state's now degenerating subjectivity, the Naxalite is imagined as some sort of a disease from which the state suffers. In the presence of some pathological conditions linked to the functioning of the state - abdication of responsibility, remote areas within its jurisdiction, corruption, poverty - Naxalism is more likely to occur (see Harivansh 2008). The state is the infected as well as the cause of the disease which has to be cured, while Naxalism is the symptom of the disease which has to be removed. So, ultimately the question turns back not to the problematic political identity that Naxalism itself poses, but to the political subjectivity of the state and potential disruption it faces because of its emerging mirror reflection in the Naxalite. 
Seen through the lens of the victim-offender framework which underpins the dual policy, it appears as though the state is the victim, the Naxalite is the offender and the people are the determining variables, who shift their loyalties and patronage based on which side performs better in delivering their needs. As part of restoring the state's legitimacy, the policies are designed to win back the people from the Naxalites.

The politics of the Naxalite Movement is imagined as opportunist and as aimed towards the capture of power. In the Expert's Report for the Ministry of Home Affairs (2008), even though Naxalite activities are associated with those responsibilities which the welfare state has abdicated, the Naxalites are debunked for not wishing to hand over their functions to the state. Their political activity is illegitimate, or rather illegitimised, against the state's own legitimacy over rule or control. Thus, the conclusion is that Naxalites flourish where there is no political activity and disrupt key parts of the political machinery - such as elections and state administration - in order to set up their own parallel regime.

However, away from the rhetoric, on the ground the political identities of the state and the Naxalite often collude, and this is damaging to the political credibility of both. In forging undercover links with the enemy, in order to win elections and to push development contracts for their constituencies, state officials put at stake the legitimacy of the state. And in courting the state, the Naxalites suggest that there is hypocrisy between their anti-state rhetoric and their actions. This became evident during the Lok Sabha elections in 2009 when, while in principle Naxalites boycotted elections and even disrupted polling booths in some regions, during the state assembly elections in Jharkhand some Maoist leaders even stood as candidates from prisons (Times News Network 2009). While the Naxalites explain their actions by claiming that they participate in elections to show the flaws in the system, in the larger scheme of things the state officials can earn their credibility back by keeping away from the Naxalite and showing that they can survive without their support. Yet for the Naxalites to earn legitimacy they have to neutralise their politics or assimilate with the state.

In dealing with the problem of the parallel regime that Naxalites have built, development is closely linked to restoring state legitimacy. At one level, it pushes good governance higher up in the agenda. In order to effectively implement its twopronged policy of security and development, the state first has to clean up its own act by removing corruption and lawlessness (Srivastava 2009). Moreover, the state has to devolve from the statuettes in its policy papers to actual physical presence with its grassroots, just as the Naxalites have done so far. Effectively, this is part of a broader strategy which one politician described as separating the fish - the Naxalites, from the water - their local support base. By proving more efficient administration and gaining more visibility amongst the people, the state can win back the public loyalty it had lost to the Naxalites.

This development approach also operates at a second level - that of delegitimizing the functions that Naxalites have been fulfilling. Evidence of Naxalites taking levies from allocated development funds feeds into their anti-development image. As power-hungry extortionists who survive on sabotaging the development process, Naxalites renew the political legitimacy of the developmental state. Some security analysts have advised the state to publicise the evidence of Naxalite corruption and degeneration to win back popular support (Kumar 2008; Kujur 
2009). As for those developmental functions which the Naxalites have carried out with much success, such as land redistribution and forest rights, the state appropriates within its own legal framework while at the same time discrediting the influence of the Naxalites. Finally, although the salience of a political solution is highlighted over a military one, as the internal enemy that keeps the state from reaching its remote population, the Naxalite Movement provides a continuing sanction for coercive measures. In the name of providing security for development, more roads and highways are planned under the Pradhan Mantri Gram Sadak Yojna (PMGSY) to enable police and military forces to enter, more police camps are set to patrol forests and more deals with private investors are settled under air raids over the tribal heartland.

\section{Naxalite movement as a political disorder: policy to normalize and discipline political action}

When the Naxalite Movement is recognised as a particular kind of political struggle, it privileges an approach based on dialogue and negotiation in order to bring the movement into the political mainstream. However, even though this perspective focuses on the 'political identity' that the Naxalite Movement represents, it addresses it as a problem not just for itself but also for the boundaries within which resistance is deemed acceptable in a parliamentary democracy. So, while there is a kind of implicit approval, particularly from left wing parties, for the political cause that the movement stands for, across the political spectrum its choice of violence is condemned. As a result, the critique of the Naxalite Movement as 'undemocratic,' 'totalitarian' and 'violent' is intended to discipline radical left wing politics so that it can fit into the framework of parliamentary democracy. Inadvertently, however, this results in re-legitimising the basic premises on which the neo-liberal order is based, while treating calls for radical transformation as somewhat elusive and impossible. The prelude for the entry of Naxalite Movement into mainstream politics is therefore to strip it off its radical political characteristics (Giri 2009).

There are three ways in which Naxalism is described as a problematic political struggle. One that is associated with its ideological ally, the Communist parties CPI and CPI(M), describes it as a 'political disorder' (Ramana 2008). Although both consider the Indian state as semi-colonial and semi-feudal, unlike the Maoists the Communist parties do not want to overthrow the state but to direct it towards being a welfare state within the realities of a neo-liberal global economy. It is from this point of departure that the subsequent dissolution of Naxalite politics begins. The Naxalites are criticised for deteriorating the ideology of class struggle by playing with emotions and frustration to advance an armed revolution. They have not understood the true character of the Indian state, as Ramana (2008) argues, not just in their estimation of the scale of its repressive potential but also in the fact that the Indian state is not entirely conservative and reactionary, but accommodative of people's demands as long as they are made through mass movements.

The critique therefore becomes an occasion to assert the possibilities within the Indian democratic system, with a people-friendly and accommodating state at its core, as well as to suggest the potential success of the democratic class struggle which has understood the 'true' character of the existing political system. In one sweep, Naxalism as an alternative political force is pushed out of the boundaries 
within which acceptable politics takes place. Acceptable politics is that which recognises the legitimacy of the state's developmental and repressive powers and makes demands within these constraints. Often in the Legislative Assembly, the Communist government in West Bengal is cited as an example where Naxalism was successfully contained because the state seriously took up redistributive measures within its policy apparatus (Singh 2004; Sar 2005). In drawing links between Communists in power and the end of Naxalism, the democratic left actually reaps the benefits of the existence of the radical left, in order to expand its own political avenues rather than the state repression it often accuses its ideological partner of bringing about.

A second perspective on the Naxalite Movement sees it as a kind or epiphenomenon or by-product of the failure of the existing system (Giri 2009). Here, the long-term ideology of state capture is set aside and seen instead as some kind of local service provider which meets the day-to-day needs of the poor. The focus is not so much on Naxalite politics for what it is, but rather on the socioeconomic conditions in which it takes place (Planning Commission 2008; Roy 2009). Unlike the view that the Naxalite Movement is a wide-scale revolutionary struggle that threatens to take over all of India, this view suggests that its effect is very much localised and representative of the poorest and neediest amongst India's population. While it dismisses the internal security challenge that the movement can potentially pose, it asks for the building of more continuities between the services Naxalites provide and the state's policy apparatus. Even here Naxalite politics is reduced to mere rhetoric and sloganeering, and the focus is rather on grasping the conditions that make the movement possible, such that it underlines the need for a more efficient welfare state.

Finally, the Naxalite Movement is seen from the perspective of organizational politics (Kujur 2008). From the history of the different political formations that make up the Naxalite Movement, it is suggested that it is a well-organized mobilization founded on a strong institutional base and a core leftist ideology which it has sustained over the years. Contrary to perspectives which consider the movement to have weakened because of in-fighting between factions and deterioration of its ideological base, this perspective asks that the movement is thought of as a force to be reckoned with. Here the urge to keep in mind the politics of Naxalism is really a call to consider its organizational base and the political manoeuvres its leading parties have been making in order to design an effective way of countering it. This view of the Naxalite Movement as a serious political force is to some extent influenced by the example of the Maoists in Nepal (LSD Radhakrishnan 2006). Occasionally mentioned in the context of advocating peace talks with Maoists, here the intention is to keep the possibility of dialogue open so that Maoists can be brought back into mainstream politics.

Overall, in assessing the Naxalite movement as a problematic political struggle, the response is based on two basic objectives - to reform the politics such that it subscribes to the rule of the democratic system or to overcome it through state policies by effectively addressing the grievances on which it is based. While this perspective keeps the door open for alternatives to coercion, in de-legitimising the politics of Naxalism it does not completely eliminate the security approach. Instead by basing politics on the fear of possible state repression, it further disciplines and contains the space for dissent. 


\section{Conclusion}

In this article, I have sought to investigate how a two-pronged policy approach, which links development with the imperative for security and state survival, impinges on the ideas and practice of development. In responding to a problem associated with poverty and inequality through a combination of military and development instruments, a distinction is made between two policy subjects - the angry rebel and the neglected poor - who could often reflect two sides of the same person. Therefore, even though the two policies are meant for different policy subjects, they are ultimately aimed at addressing the same problem, namely the rise of left wing extremism. As a result, in the process of controlling internal dissent there are points at which security and development goals coincide with each other. By looking at three representations of the problem of Naxalism I have attempted to make visible these points of convergence - from the way in which the problem and the subject of intervention is defined, from the way in which development measures are prescribed and from the way in which the developmental state and its security apparatus is legitimised.

Each of the three types of representation that we have looked at tilts the scales of the law and order approach and the socio-economic approach to different levels. In the Naxalism as terrorism version, development initiatives are collapsed within the security imperative and are taken as part of the counter-insurgency strategy. The Naxalite Movement as a parallel regime account focussed mainly on the socioeconomic approach, but oriented it towards restoring the state's political legitimacy. Finally, the version that viewed the Naxalite Movement as a problematic political struggle kept the door open for non-coercive means such as peace talks and political mainstreaming, but at the same time sought to 'normalise' politics within the reality of a neo-liberal state that is intolerant of violent resistance.

Overall, the effect of linking development with security has the effect of feeding development goals into security goals such as state legitimacy, state survival and maintaining the stability of the system. As a result, even though more funds are given through different state and central government initiatives to help neglected and relatively backward regions to catch up, it does not necessarily transform those aspects of development which caused violent resistance in the first place. Instead it lends a kind of urgency to development - the speedier that development initiatives can show results, the more effective it will be in winning back the support of the poor and the legitimacy of the developmental state. Consequently, the response has concentrated more on increasing the visibility and pace of development activities through funds for backwards regions, contracts to construct roads and highways, employment guarantee acts and posting more police officers and administrative personnel in remote areas. In contrast, the effort to change some negative consequences of development, such as instituting a legally binding resettlement and rehabilitation policy or changing the terms of Special Economic Zones for private investors, has been much slower.

A more critical effect of the development security link has been in the creation of an 'internal enemy'. In the name of flushing out dissenters who stand in the way of development, coercive measures can be taken to erase contestation and resistance around state-directed development. 
On the other hand, with the advent of security discourse into non-traditional issues associated with human security (livelihood, food and identity), it may have been possible for security to have been broadened beyond traditional concerns of state survival and military strength. However, in response to left wing insurgency in India, security discourse has dissolved developmental issues within its scope, to the extent that when pressing concerns of poverty are seen through the security lens these are taken as part of an existential threat, a non-debateable issue vital to the survival of the country. The issue of poverty is taken from the logic of emancipation of the slow and deliberative politics of democracy and universal norms, to the logic of security where politics is based on exceptions as well as urgency and speed. To conclude I would suggest that a meaningful response to the rise of left wing extremism would be one that is cautious of the effects that a narrow security lens can have on development. Poverty and inequality are crucial to human security, but at the same time have to be addressed through democratic politics. Instead of directing development towards state survival, a tighter link between development and guarantees for socio-economic justice would be better placed to resolve the problem. And finally, it is important to recognise the extreme left as a political movement in order to keep the space for negotiation open. Politics that arms the poor with the ideology of violence, however illegitimate, can only be resolved if it is negotiated with as one kind of political demand.

\section{Notes}

1. The development programmes include the following: Backward Development Initiative, Backward Regions Grant Fund, Pradhan Mantri Gram Sadak Yojna, National Rural Employment Guarantee Scheme, Sarva Shiksha Abhiyan and National Rural Health Mission Scheme. The security programmes include the following: security-related expenditure through which state governments are reimbursed some of the costs incurred for building its law and order apparatus, Police Modernization Scheme and the deployment of paramilitary forces.

2. In Jharkhand alone, as Kelly and Shah (2006) observes, by 2004, 234 people were arrested, more than 650 had cases pending against them and more than 3200 people were named as involved in terrorist activities.

\section{References}

Ahuja, P., and R. Ganguly. 2007. The fire within: Naxalite insurgency violence in India. Small Wars and Insurgencies 18, no. 2: 249-74. http://164.100.24.208/debate14/debtext.asp? slno $1 / 44001 \& \operatorname{ser}^{1 / 4} \& \operatorname{smode}^{1 / 4}$ (accessed November 11, 2007).

Bacchi, C. 2000. Policy as discourse: What does it mean where does it get us? Discourse: Studies in The Cultural Politics of Education 21, no. 1: 45-57.

Balagopal, K. 2006. Maoist Movement in Andhra Pradesh. Economic and Political Weekly. July 22: 3183-7.

Banerjee, S. 1980. India's simmering revolution: The Naxalite uprising. London: Zed Books.

Bhatia, B. 2000. The Naxalite movement in central Bihar. Unpublished PhD diss., University of Cambridge.

Bhatia, B. 2006. On armed resistance. Economic and Political Weekly. July 22: 3179-83.

Buzan, B., and O. Waever. 1997. Slippery, contradictory? Sociologically untenable? The Copenhagen School Replies. Review of International Studies 23, no. 2: 241-50.

Buzan, B., O. Waever, and J. Wilde. 1998. Security: A new framework for analysis. Boulder: Lynne Rienner.

Chakraborty, A. 2005. Speech given in Lok Sabha for Part 2 of Discussion regarding Naxalite attacks in Jharkhand and Bihar.

Chaliha, K. 2004. Discussion in Lok Sabha regarding matters relating to internal security in the country, December 13, 2004. http://164.100.24.208/debate14/debtext.asp?slno $1 / 41038$ \&ser $1 / 4$ \&smode $1 / 4$ (accessed February 11, 2008).

Economist. 2006. A spectre haunting India. Economist. September 2006.

Garg, R. 2008. Roots and causes: The case of Dandakaranya. In The Naxal challenge: Causes, linkages and policy options, ed. P.V. Ramana. Delhi: Dorling Kindersley.

Giri, S. 2009. "The Maoist 'Problem' and the democratic Left in India". Journal of 
Contemporary Asia 39, no. 3: 463-74.

Gupta, R.J. 2004. The crimson agenda: Maoist protest and terror. Delhi: Wordsmiths.

Harivansh. 2008. Roots and causes: The case of Jharkhand. In The Naxal callenge: Causes, linkages and policy options, ed. P.V. Ramana, 18-24. Delhi: Dorling Kindersley.

Harris-White, B. 2003. India working: Essays on society and economy. Cambridge: Cambridge University Press.

Hawkesworth, M. 1988. Theoretical issues in policy analysis. New York: State University of New York Press.

Iyer, L. 2009. The bloody millennium: Internal conflict in south Asia. BGIE Working Paper No. 09-086, Harvard Business School.

Kelly, T., and A. Shah. 2006. Markets of protection: The 'Terrorist' Maoist and the state in Jharkhand, India. Critique of Anthropology 26: 297-314.

Kujur, R. 2009. Underdevelopment and the Naxal movement. New Delhi: Institute of Peace and Conflict Studies. Article 2937.

Kujur, R. 2008. Naxal movement in India: A profile IPCS Research Paper. IPCS, New Delhi

Kumar, N. 2004. Untitled. Discussion in Lok Sabha regarding matters relating to internal security in the country, December 13, 2004. http://164.100.24.208/debate14/debtext.asp? slno $1 / 41038 \&$ ser $^{1 / 4}$ \&smode $1 / 4$ (accessed February 11, 2008).

Kumar, N. 2005. Untitled. Speech given in Lok Sabha for Part 1 of discussion on Naxalite attacks in Jharkhand and Bihar, December 7, 2005. http://164.100.24.208/debate14/ debtext.asp?slno $1 \frac{1}{438}$ 60\&ser $1 / 4 \& \operatorname{smode}^{1 / 4}$ (accessed December 2007).

Kumar, S. 2008. Changing face of the Naxalites in Bihar: From homelessness to real estate. New Delhi: Institute of Peace and Conflict Studies. Article 2608.

Louis, P. 2000. People power: The Naxalite movement in central Bihar. Delhi: Wordsmiths.

Mahtab, B. 2005. Untitled. Speech given in Lok Sabha for Part 2 of Discussion regarding Naxalite attacks in Jharkhand and Bihar, December 8, 2005. http://164.100.24.208/ debate14/debtext.asp?sln 01/44001\&ser $1 / 4 \&$ smode $^{1 / 4}$ (accessed November 11, 2007).

Malhotra, 2006. Untitled. Speech given in Lok Sabha for discussion on situation arising out of increasing Naxalite and Maoist activities in the country, May 22, 2006. (Translated from Hindi) http://164.100.24.208/debate14/debtext.asp?slno $1 / 45398 \&$ ser $^{1} / 4 \&$ smode $^{1} / 4$ (accessed December 2007).

Ministry of Home Affairs, 2007. Annual Report 2007-2008. Ministry of Home Affairs, Government of India, New Delhi.

Ministry of Home Affairs, 2008. Annual Report 2008-2009. Ministry of Home Affairs, Government of India, New Delhi.

Mukherjee, A.P. 2007. Maoist spring thunder: The Naxalite movement 1967-1972. Kolkata: K.P. Bagchi and Company.

Mukhopadhyay, A.K. 2006. The Naxalites through the eyes of the police. Kolkata: Dey's Publishing.

Nayak, N. 2008. Maoists in Nepal and India: Tactical alliances and ideological differences. Strategic Analysis 32, no. 3: 459-75.

Patil, S. 2005a. Untitled. Speech given in Lok Sabha, April 24, 2005. http://164.100.24.208/ debate14/debtext. asp?slno $1 / 43860 \&$ ser $^{1 / 4} \&$ smode $^{1 / 4}$ (accessed December 2007).

Patil, S. 2005b. Untitled. Speech given in Lok Sabha for Part 1 of discussion on Naxalite attacks in Jharkhand and Bihar, December 7, 2005.

Planning Commission, 2008. Development challenges in extremist affected areas: Report of an expert group to planning commission. Planning Commission, Government of Delhi, New Delhi.

Podder, S. 2007. The politics of gun control and India's internal security. Strategic Analysis 31, no. 4: 675-87.

Radhakrishnan, V. 2006. Untitled. Speech given in Lok Sabha for discussion on situation arising out of increasing Naxalite and Maoist activities in the country, May 22, 2006 http://164. 100.24.208/debate14/debtext.asp?slno $1 / 45398 \&$ ser $^{1} / 4 \&$ smode $^{1 / 4}$ (accessed December 2007).

Ramana, P.V. 2008. The Maoist web: An overview. In The Naxal callenge: Causes, linkages and policy options, ed. P.V. Ramana, ix - iv. Delhi: Dorling Kindersley.

Rao, R. 2009. Aerial support for countering Naxals. New Delhi: Institute of Peace and Conflict Studies. Article no. 2981.

Ray, R. 1988. Naxalites and their ideology. Delhi: Oxford University Press.

Reddy, M.S. 2008. A political approach to the Naxalite problem: Viability and prerequisites for success. In The Naxal callenge: Causes, linkages and policy options, ed. P.V. Ramana, 39-61. Delhi: Dorling Kindersley.

Roy, A. 2009. The heart of India is under attack. Guardian, October 30. http://www.guardian. 
co.uk/comment is free/2009/oct/30/mining-india-maoists. (accessed November 1, 2009).

Roy, A.K. 1975. The spring thunder and after. Calcutta: Minerva Associates.

Sar, N. 2005. Untitled. Speech given in Lok Sabha for Part 2 of Discussion regarding Naxalite attacks in Jharkhand and Bihar, December 8, 2005. http://164.100.24.208/debate14/ debtext.asp?slno $1 / 440$ 01\&ser $1 / 4 \&$ smode $^{1} / 4$ (accessed November 11, 2007).

Shapiro, M. 1997. Winning the West, unwelcoming the immigrants: Alternative stories of America.' In Tales of the state: Narrative in Contemporary US Politics and Public Policy, ed. S. Schram and P.T. Neisser, 17-26. New York: Rowman and Littlefield Publishers Inc.

Singh, M. 2004. Untitled. Discussion in Lok Sabha regarding matters relating to internal security in the country, December 13, 2004. http://164.100.24.208/debate14/debtext.asp?sl no $1 / 41038 \&$ ser $^{1 / 4} \&$ smode $^{1 / 4} / 4$ (accessed February 11, 2008).

Singh, P. 1995. The Naxalite movement in India. New Delhi: Rupa and Co.

Srivastava, D. 2009. Review of chief ministers' conference on Naxalism. New Delhi: Institute of Peace and Conflict Studies. Article no. 2954.

Srivastava, D. 2008. Fighting Naxals. New Delhi: Institute of Peace and Conflict Studies Article no. 2631.

Strategic Comments. 2010. Rising extremism in South Asia. Strategic Comments 16, no. 1: 13.

Swain, K. 2006. Untitled. Speech given in Lok Sabha for discussion on situation arising out of increasing Naxalite and Maoist activities in the country, May 22, 2006. http://164. 100.24.208/debate14/debtext.asp?slno $1 / 45398 \&$ ser $^{1} / 4 \&$ smode $^{1} / 4$ (accessed December 2007).

Tharu, S. 2007. Insurgency and the state in India: The Naxalite and Khalistan movements. South Asian Survey 14, no. 83: 83-100.

Times News Network, 2009. 4-Way split leave Jharkhand Shaky. Times of India, December 24, 2009.

Williams, M.C. 2003. Words, images, enemies: Securitization and international politics. International Studies Quarterly 47, no. 1: 511-31. 